\title{
Anopheles species composition explains differences in Plasmodium transmission in La Guajira, northern Colombia
}

\author{
Manuela Herrera-Varela', Lorena I Orjuela', Cilia Peñalver², Jan E Conn ${ }^{3,4}$, Martha L Quiñones ${ }^{1 /+}$ \\ 'Public Health Department, Faculty of Medicine, National University of Colombia, Bogotá, Colombia \\ ${ }^{2}$ Secretaria Departamental de Salud, La Guajira, Colombia ${ }^{3}$ The Wadsworth Center, New York State Department of Health, Albany, NY, USA \\ ${ }^{4}$ Department of Biomedical Sciences, School of Public Health, State University of New York, Albany, NY, USA
}

Malaria in La Guajira, the most northern state of Colombia, shows two different epidemiological patterns. Malaria is endemic in the municipality of Dibulla whereas in Riohacha it is characterised by sporadic outbreaks. This study aimed to establish whether differences in transmission patterns could be attributed to different vector species. The most abundant adult female species were Anopheles aquasalis, exclusive to Riohacha, and Anopheles darlingi, restricted to Dibulla. Anopheles mosquitoes were identified using morphology and the molecular markers internal transcribed spacer 2 and cytochrome c oxidase I. All specimens $(n=1,393)$ were tested by ELISA to determine natural infection rates with Plasmodium falciparum and Plasmodium vivax. An. darlingi was positive for P. vivax 210 , with an infection rate of $0.355 \%$ and an entomological inoculation rate of 15.87 infective bites/person/year. Anopheles albimanus larvae were the most common species in Riohacha, found in temporary swamps; in contrast, in Dibulla An. darlingi were detected mainly in permanent streams. Distinctive species composition and larval habitats in each municipality may explain the differences in Plasmodium transmission and suggest different local strategies should be used for vector control.

Key words: Anopheles - Plasmodium - malaria

In Colombia, malaria is the most important vectorborne disease, with an average of 123,000 cases per year during the last decade (WHO 2012). Plasmodium vivax is responsible for $62.9 \%$ of these cases; Plasmodium falciparum for $37 \%$ and Plasmodium malariae for 0.1\% (WHO 2012). In the northern state of La Guajira, in the Caribbean region, malaria has not been a major public health problem except in the foothills of the Sierra Nevada de Santa Marta, particularly in the municipality of Dibulla where P. falciparum malaria cases predominated every year in the 90's (Cáceres et al. 2000). Nevertheless, since the mid-1990s a rise in the overall number of cases has been consistently reported. Between 19901995 , the average annual number of cases ranged from 40-150. This increased to 500 between 1997-1998. An exponential increment of cases was reported in the period December 1999-November 2000. A total number of 5,853 cases and 12 deaths were reported, by far the largest outbreak reported in this region. The municipalities of Riohacha and Dibulla were the most affected (González 2000). After this period, cases decreased to an average

doi: 10.1590/0074-0276140126

Financial support: COLCIENCIAS [award for the Project: Determining the role as a malaria vector species Anopheles in three regions of Colombia (110134319196) to MLQ], USA NIH (AI R0154139-02 to JEC)

+ Corresponding author: marthalquinones@gmail.com

Received 11 April 2014

Accepted 19 August 2014 of 150 between 2000-2007. In 2008-2009, another outbreak occurred in which Dibulla was the most affected, contributing 1,617 cases out of 3,041, mainly caused by $P$. vivax (SIVIGILA 2013). Subsequently, a Global Fund project (PAMAFRO 2011) intensified the distribution of insecticide treated nets in Dibulla and malaria cases declined to 148 cases (10\% of the state) (SIVIGILA 2013).

Even though Riohacha and Dibulla have been the localities most affected during malaria outbreaks, ecological conditions and epidemiological patterns of the disease are distinctive in each municipality. Riohacha is located in a desert valley and cases of malaria, mainly $P$. vivax, only appear in high numbers at the end of the rainy season during the last few months of the year. On the other hand, Dibulla is located in the foothills of the Sierra Nevada de Santa Marta, where malaria is endemic, cases of P. falciparum were more common in the 90's (Cáceres et al. 2000) and P. vivax predominated from the 2008-2009 outbreak (SIVIGILA 2013).

Entomological studies conducted in this region are scarce. In 1957 the former Malaria Eradication Service (SEM) reported the presence of nine species of Anopheles (*currently known as species complex): Anopheles albimanus Wiedemann, Anopheles pseudopunctipennis* Theobald, Anopheles darlingi Root, Anopheles triannulatus* (Neiva \& Pinto), Anopheles punctimacula Dyar \& Knab, Anopheles albitarsis* Galvão \& Damasceno, Anopheles aquasalis Curry, Anopheles argyritarsis Robineau-Desvoidy and Anopheles neomaculipalpus Curry (SEM 1957). Studies carried out during the 19992000 malaria outbreak recorded eight species, seven of which had already been registered by SEM and one species, Anopheles trinkae Faran, 1979, reported for the first time in this area (Cáceres et al. 2000). Among these 
species An. albimanus was proposed as the main malaria vector based on its abundance and presence at all sampling sites, but natural infectivity rates were not measured (Cáceres et al. 2000, Porras et al. 2001). However, species well-known as malaria vectors in other Neotropical countries, such as An. darlingi, An. pseudopunctipennis s.l. and An. aquasalis (Grillet 2000, Sinka et al. 2010, Hiwat \& Bretas 2011) are also present in La Guajira and may be involved in local transmission.

Given the differences in Plasmodium transmission in Dibulla and Riohacha and the diversity of species reported in La Guajira, this study aimed to identify the species of Anopheles present in these two municipalities and to determine their natural infectivity with Plasmodium as a first step to incriminate the malaria vectors in the region.

La Guajira is the northern most part of South America, bounded by the Caribbean and Bolivarian Republic of Venezuela. Riohacha is the state capital and has approximately 170,000 inhabitants in an area of 20,848 $\mathrm{km}^{2}$. It is located in a desertic area with annual rainfall of $1,000 \mathrm{~mm}$. Dibulla has a population of 21,078, an area of $6,633 \mathrm{~km}^{2}$ and is characterised by humid tropical forest weather with 3,000-5,000 $\mathrm{mm}$ rainfall/year (Gobernación de La Guajira 2008).

Within each municipality, a household was selected taking into account local malaria endemicity, the presence of Anopheles mosquitoes and the feasibility of access throughout the sampling period: Radio Delfin in Riohacha 11 $32^{\prime} 645^{\prime \prime} \mathrm{N} 72^{\circ} 53^{\prime} 944^{\prime \prime} \mathrm{W}$ and Las Flores in Dibulla $11^{\circ} 14^{\prime} 813^{\prime \prime} \mathrm{N} 73^{\circ} 09^{\prime} 951^{\prime \prime} \mathrm{W}$ (Fig. 1). Five mosquito surveys of four days each were conducted between 2007-2008 in both localities, including three surveys in the dry season (May 2008-July 2007, 2008) and two during the rainy season (August-September 2008).

Human landing catches (HLC) were undertaken from 06:00 pm-06:00 am during the first night in each sampling area to determine the peak of activity of anthropophilic mosquitoes. Consecutive HLC were car-

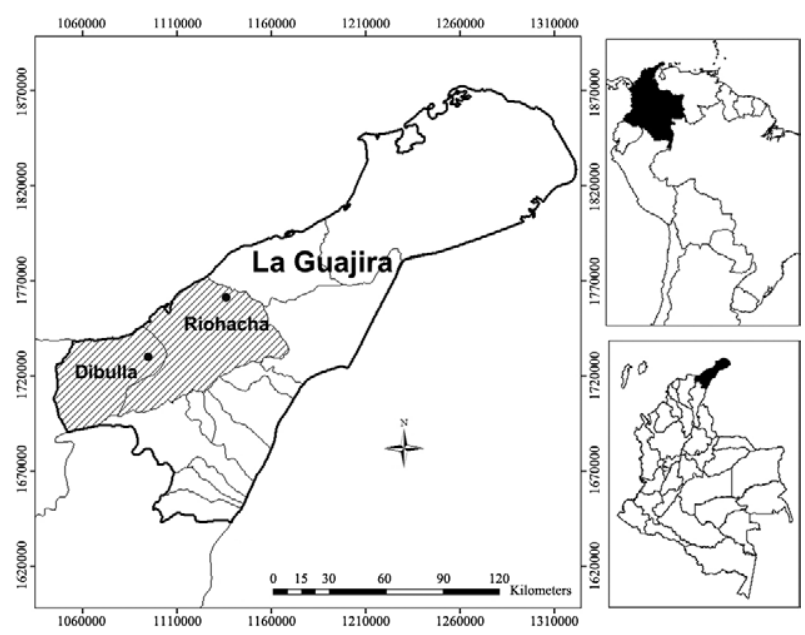

Fig. 1: map of the study area, department of La Guajira, Colombia,

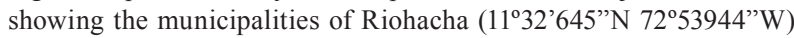
and Dibulla $\left(11^{\circ} 14^{\prime} 813^{\prime \prime N} 73^{\circ} 09^{\prime} 20^{\prime \prime} \mathrm{W}\right)$. Dots indicate the exact location of sampling households. ried out only during the biting peak between 08:00 pm12:00 am. Each catch was conducted for intervals of 50 min followed by $10 \mathrm{~min}$ of observation on the surfaces of houses to search for resting mosquitoes. One collector was located inside and another was outside each house simultaneously and they switched positions every hour to avoid bias due to differences in attractiveness or catching ability. Mosquitoes collected were killed the next day in lethal chambers with ethyl acetate. Then they were packed individually in $0.5 \mathrm{~mL}$ Eppendorf tubes and stored in bags containing silica gel. Data were analysed using geometric means to determine the biting rate, interpreted as the average number of bites $/$ human $/ \mathrm{h}$ indoors and outdoors. A student $t$ test was used to determine if there was a difference between the average of mosquitoes collected during the dry and rainy seasons. Additionally, nightly collections were made in animal shelters, most often in cattle and goats stables, by actively searching for resting mosquitoes in a radius of 100 $\mathrm{m}$ around each house.

In each locality searching for breeding sites was conducted within $100 \mathrm{~m}$ of each of the houses. Sampling was done by dipping 10 times per $\mathrm{m}^{2}$ with a standard dipper $(350 \mathrm{~mL})$. Collected larvae were maintained for linked rearing and the larval and pupal skins kept for taxonomic determination.

All collected specimens were identified based on morphological traits (González \& Carrejo 2009). Identifications were confirmed by internal transcribed spacer (ITS)2[ITS2F(5'-TGTGAACTGCAGGACACATGAA-3') and ITS2R (5'-ATGCTTAAATTTAGGGGGTAGTC-3')] and cytochrome c oxidase I (COI) [TY-J-1400 (5'-TACAATTTATCGCCTAAACTTCAGCC-3') and UEA-6 (5'-TTAATTCCTGTAGGNACAGCAATAATTAT-3')].

The determination of mosquitoes naturally infected with Plasmodium was performed following the standard methodology of the ELISA kit distributed by the Centers for Disease Control (USA) using $P$. vivax 210, 247 and $P$. falciparum monoclonal antibodies.

This study was approved by the Ethical Committee of the Faculty of Medicine of the National University of Colombia, protocol 1608.

Considering morphological characteristics and ITS2 and $C O I$ sequences, seven species of Anopheles were identified for the region: An. albimanus (KC354815-7, KC3548224-5), An. aquasalis (KC354812-3, KC354821), An. darlingi (KC894593-5), An. punctimacula (KC354809, KC354818), An. pseudopunctipennis s.l. (KC354810-1, KC354819-20), An. argyritarsis and An. triannulatus s.l.

A total of 1,343 specimens were collected by HLC and 47 larval series were successfully reared. A similar proportion of specimens were collected in each municipality, however, the species composition was different. In Riohacha, An. albimanus larvae was found in a swamp and in a well, as well as in sympatry with $A n$. pseudopunctipennis s.l. in a stream margin (total $=17$ ). In Dibulla An. albimanus, An . darlingi, An . argyritarsis, An. punctimacula and An. pseudopunctipennis s.l. were collected in a stream margin (total $=30$ larvae). 
TABLE

Anopheles species caught by human landing catches (HLC) and resting outdoors in the municipalities of Riohacha and Dibulla, Colombia, 2008-2009

\begin{tabular}{|c|c|c|c|c|c|c|c|c|c|c|}
\hline \multirow[b]{3}{*}{ Municipality } & \multirow[b]{3}{*}{ Species } & \multicolumn{7}{|c|}{ HLC } & \multirow[b]{3}{*}{ Resting } & \multirow[b]{3}{*}{ Total } \\
\hline & & \multicolumn{3}{|c|}{ Dry season } & \multicolumn{3}{|c|}{ Rainy season } & \multirow{2}{*}{$\begin{array}{l}\text { Student } t \text { test } \\
\text { (p) }\end{array}$} & & \\
\hline & & GM & $95 \% \mathrm{CI}$ & $\mathrm{n}$ & GM & $95 \% \mathrm{CI}$ & $\mathrm{n}$ & & & \\
\hline \multirow[t]{2}{*}{ Riohacha } & An. aquasalis & 0.24 & $0-0.9$ & 30 & 82.7 & $55.1-124$ & 639 & $12.03(<0.001)$ & - & 669 \\
\hline & An. albimanus & - & - & 0 & 2.81 & $0.1-11.8$ & 58 & - & - & 58 \\
\hline \multirow[t]{5}{*}{ Dibulla } & An. darlingi & 17.64 & $9.7-31.2$ & 458 & 5.26 & $2.6-9.6$ & 45 & $2.57(0.018)$ & 17 & 520 \\
\hline & An. albimanus & 3.93 & $2.2-6.4$ & 85 & 1.1 & $0.3-2.4$ & 10 & $2.57(0.017)$ & 6 & 101 \\
\hline & An. punctimacula & - & - & 1 & - & - & 0 & - & 1 & 2 \\
\hline & An. triannulatus s.l. & - & - & 0 & 0.64 & $0-1.5$ & 6 & - & 25 & 31 \\
\hline & An. pseudopunctipennis s.l. & 0.46 & $0.14-0.87$ & 9 & 0.22 & $0-0.6$ & 2 & $0.92(0.36)$ & 1 & 12 \\
\hline Total & & - & - & 583 & - & - & 760 & - & 50 & 1,393 \\
\hline
\end{tabular}

CI: confidence intervals; GM: geometric means.

\section{An. darlingi}

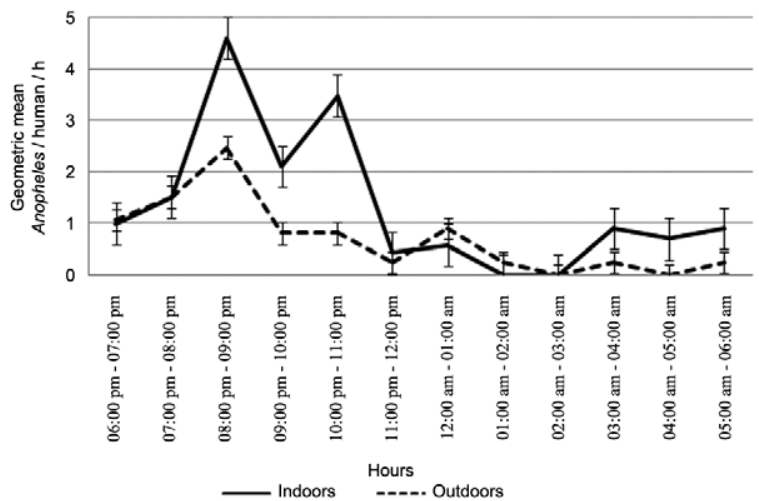

An. aquasalis

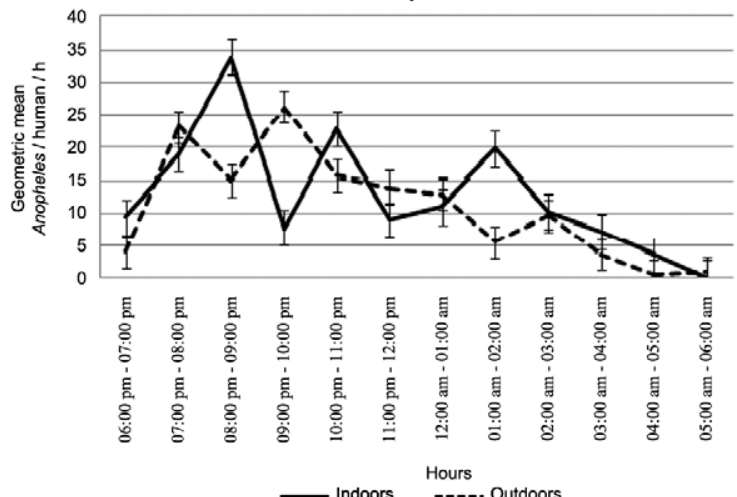

Fig. 2: human landing activity of Anopheles aquasalis in the municipality of Riohacha and Anopheles darlingi in the municipality of Dibulla, La Guajira, Colombia.

From HLC the most abundant species was An. aquasalis (48\%), collected only in Riohacha, followed by $A n$. darlingi (37.3\%), found only in Dibulla. An. albimanus was collected in both municipalities at low densities (11.4\%). Other species such as An. punctimacula, An. triannulatus s.l. and An. pseudopunctipennis s.l. were found in lower abundance representing $3.2 \%$ of the total catches (Table). No evidence was found of the presence of An. trinkae, as previously reported in this region (Cáceres et al. 2000).

The abundance of An. aquasalis and An. albimanus in Riohacha increased as the rainy season progressed, whereas in Dibulla a higher abundance of An. darlingi was found during the dry season. The differences between the two seasons in the geometric mean number of the mosquitoes collected for each of those species were statistically significant (Table). Resting mosquitoes ( $\mathrm{n}=$ 50) were only collected outdoors in Dibulla near goats (Capra hircus) stables. The most abundant species associated with goats, the most common regional domestic animal, were An. triannulatus s.l. (50\%), followed by An. darlingi (34\%) and An. albimanus (12\%) (Table).

Human landing activity was measured by hour for the most abundant species in each area, An. aquasalis in Riohacha and An. darlingi in Dibulla. An. aquasalis was present throughout the night, both indoors and outdoors, with a slight decrease in its activity after 02:00 am. For this species the biting rate was 153 bites/human/night. $A n$. darlingi showed a higher activity during the first six hours of the night, both indoors and outdoors. After midnight, its density dropped, but the species was still present. For An. darlingi the biting rate was 12.24 bites/ human/night (Fig. 2).

All field-collected adult specimens were tested by ELISA. Only An. darlingi $(\mathrm{n}=2)$ was positive for the circumsporozoite protein of $P$. vivax 210 . The positive samples were collected in Dibulla at 01:00 am in July 2008 at the end of the dry season. Infection rate was 0.355 and the estimated entomological inoculation rate (EIR) for this species was 15.8 infective bites/person/year. 
Plasmodium transmission in La Guajira is characterised by outbreaks. This explains the intermittent nature of vector control programmes, based primarily on the treatment of mosquito larval habitats with biological larvicides such as Bacillus sphaericus and indoor residual spraying, usually with deltamethrin $\left(0.02 \mathrm{~g} / \mathrm{m}^{2}\right)$. From 2008, when the Global Fund project (PAMAFRO 2011) began, the use of insecticide treated nets has been promoted and distributed by the malaria program, particularly for Dibulla. However, efficiency and effectiveness of these control measures remain unknown, in part because little information regarding the role of different species of Anopheles in Plasmodium transmission was obtained prior to insecticide treated net usage to enable an objective evaluation.

In our study we found that different species of Anopheles are correlated with different geographic areas and type of Plasmodium transmission. In Riohacha, An. aquasalis was the most abundant species, followed by An. albimanus and An. pseudopunctipennis s.l. The latter was collected only in the larval stage. In Dibulla a higher diversity of species was found, with An. darlingi predominating. Although the two collection sites are only separated by $53 \mathrm{~km}$, the difference in species composition might be due to the type of larval habitats in each municipality. Riohacha had a higher proportion of temporary larval habitats $(61.5 \%, \mathrm{n}=13)$, characterised by large flooded areas present mainly during the rainy months. The remaining proportion $(38.5 \%)$ consisted of permanent larval habitats, specifically man-made wells, in which only An. albimanus larvae were found. In our collection sites we did not find breeding sites for $A n$. aquasalis, despite the adult density and the presence of saline mangroves referred to as preferred larval habitats for this species (Berti et al. 1993, Grillet 2000). In Dibulla, temporary larval habitats accounted for only $9.1 \%(\mathrm{n}=11)$ and mainly consisted of animal tracks. In this municipality the most important larval habitats were permanent streams with slow currents, partial shade and emergent vegetation, which are known to be suitable habitats for several Anopheles species including An. darlingi (Faran 1980, Sinka et al. 2010).

In Dibulla, An. darlingi was positive for P. vivax 210, with an infection rate of $0.35 \%$. The present finding, in combination with high anthropophily, confirms the role of An. darlingi as the primary vector in this region. This result widens the geographic range within which this species has been established as the main malaria vector, adding La Guajira to the eastern region of Colombia, including the Amazon and other regions like Urabá, Bajo Cauca and Magdalena in the northwest of the country (Olano et al. 2001, Gutierrez et al. 2010, Ahumada et al. 2012).

The EIR for An. darlingi was 15 infective bites/person/year, about one/month, and may explain the endemicity of malaria in this area. The EIR reported in this study is similar to that reported for this species in French Guiana where the values for the three localities were 22.8, 27.4 and 14.4 (Girod et al. 2008), but much lower than the rate of 129 reported in the region of Ocamo, in the Venezuelan Orinoco (Magris et al. 2007). These differences in the EIR for the same species might be due to the biting rates reported in different geographic areas rather than the sporozoite rate, considering the similarities in the infectivity results in the different areas and the wide range of densities. This may be relevant as it shows the capacity of this species to maintain transmission even at a low density.

In the Riohacha area, neither An. aquasalis nor An. albimanus were positive for the circumsporozoite protein. Studies in Brazil and Venezuela (Berti et al. 1993, Povoa et al. 2003), where An. aquasalis is a recognised vector, have found infection rates between 0.7-1.18, suggesting that the number of mosquitoes tested in the present study $(n=690)$ was probably not sufficient to determine the natural infection in this species. Additionally, An. aquasalis and An. albimanus have mainly zoophilic behaviour (Zimmerman 1992) which implies that high densities of either species is needed to have a major impact in Plasmodium transmission (Deane 1986, Berti et al. 1993, Montoya-Lerma et al. 2011).

In conclusion, the type of Plasmodium transmission in La Guajira seems to be related to the Anopheles species present. In Dibulla the vector is An. darlingi and therefore, due to anthropophilic behaviour and indoor biting throughout the night, the use of insecticide treated nets is recommended as a method of local control. However, any complementary control activity to reduce the human-vector contact might be beneficial, because of An. darlingi activity in the earlier part of the night when people might be outdoors. In Riohacha, where the potential vectors appear to be An. albimanus and $A n$. aquasalis, personal protection and treatment of breeding sites should be the main control strategy, alongside any complementary indoor control activities such as residual spraying or the use of insecticide treated nets.

\section{ACKNOWLEDGEMENTS}

To The Wadsworth Center, New York State Department of Health, for the sequencing facilities, to Martha Liliana Ahumada, for continued support through the NHI Colombia, to the officials of the Ministry of Health of La Guajira, to Zulibeth Florez, Anibal Torres and Alex Cantillo, for providing epidemiological information and support in the field trips, to Lucas Andrés Alcalá, for his help in the collection of specimens, and to the people of Riohacha and Dibulla, for allowing access to their homes during the study.

\section{REFERENCES}

Ahumada ML, Pareja PX, Buitrago LS, Quiñones ML 2012. Comportamiento de picadura de Anopheles darlingi Root, 1926 (Diptera: Culicidae) y su asociación con la transmisión de malaria en Villavicencio (Colombia). Biomedica 33: 241-250.

Berti J, Zimmerman R, Amarista J 1993. Spatial and temporal distribution of anopheline larvae in two malarious areas in Sucre state, Venezuela. Mem Inst Oswaldo Cruz 88: 353-362.

Cáceres DC, de la Hoz F, Nicholls S, de Antonio R, Velandia MP, Olano V, Montoya R, Pinzon E, Garcia M, Florez AC, Bruzón L, Burbano ME, Bonivento J 2000. Brote de malaria en La Guajira, 1 de diciembre de 1999 a 1 de febrero de 2000. Biomedica 20: 152-161.

Deane LM 1986. Malaria vectors in Brazil. Mem Inst Oswaldo Cruz 81 (Suppl. II): 5-14. 
Faran ME 1980. Mosquito studies (Diptera: Culicidae) XXXIV. A revision of the Albimanus section of the subgenus Nyssorhynchus of Anopheles. Contrib Amer Ent Inst 15: 1-215.

Girod R, Gaborit P, Carinci R, Issaly J, Fouque F 2008. Anopheles darlingi bionomics and transmission of Plasmodium falciparum, Plasmodium vivax and Plasmodium malariae in Amerindian villages of the Upper-Maroni Amazonian forest, French Guiana. Mem Inst Oswaldo Cruz 103: 702-710.

Gobernación de La Guajira 2008. Nuestras alcaldías. Available from: laguajira.gov.co/web/.

González A 2000. Epidemia de malaria en La Guajira: una muestra lamentable de la situación de salud pública en el país. Biomedica 20: $151-152$.

González R, Carrejo NS 2009. Introducción al estudio taxonómico de Anopheles de Colombia. Claves y notas de distribución, Programa Editorial Universidad del Valle, Cali, 260 pp.

Grillet ME 2000. Factors associated with distribution of Anopheles aquasalis and Anopheles oswaldoi (Diptera: Culicidae) in a malarious area, northeastern Venezuela. J Med Entomol 37: 231-238.

Gutierrez LA, Gómez GF, González JJ, Castro MI, Luckhart S, Conn JE, Correa MM 2010. Microgeographic genetic variation of the malaria vector Anopheles darlingi Root (Diptera: Culicidae) from Cordoba and Antioquia, Colombia. Am J Trop Med Hyg 83: 38-47.

Hiwat H, Bretas G 2011. Ecology of Anopheles darlingi Root with respect to vector importance: a review. Parasit Vectors 4: 1-13.

Magris M, Rubio-Palis Y, Menares C, Villegas L 2007. Vector bionomics and malaria transmission in the Upper Orinoco River, Southern Venezuela. Mem Inst Oswaldo Cruz 102: 303-311.

Montoya-Lerma J, Solarte YA, Giraldo-Calderón GI, Quiñones ML, Ruiz-López F, Wilkerson RC, González R 2011. Malaria vector species in Colombia - A review. Mem Inst Oswaldo Cruz 106 (Suppl. I): 223-238.
Olano VA, Brochero HL, Sáenz R, Quiñones ML, Molina JA 2001. Mapas preliminares de la distribución de especies de Anopheles vectores de malaria en Colombia. Biomedica 21: 402-408.

PAMAFRO 2011. Control de la malaria en las zonas fronterizas de la región andina: un enfoque comunitario integración andina y suramericana en salud. Available from: orasconhu.org/pamafro/ presentaci\%C3\%B3n.

Porras A, de la Hoz F, Velandia M, Olano VA, Cáceres D, Rojas L, Murillo Z, Mendoza M, García M, Nicholls S, Montoya R, Pinzón E, Bruzón L, Burbano M, Mendoza E, Riaño U 2001. Epidemia de malaria en La Guajira, enero a noviembre del 2000: balance final. Sivigila 6: 1-24.

Povoa MM, Conn JE, Schlichting CD, Amaral JC, Segura MN, da Silva AN, dos Santos CC, Lacerda RN, de Souza RT, Galiza D, Rosa EPS 2003. Malaria vectors, epidemiology, and the re-emergence of Anopheles darlingi in Belem, Pará, Brazil. J Med Entomol 40: $379-386$.

SEM - Servicio de Erradicación de Malaria 1957. Plan para la erradicación de la malaria en Colombia, Oficina Regional de la Organización Mundial de la Salud, Bogotá, 235 pp.

Sinka ME, Rubio-Palis Y, Manguin S, Patil AP, Temperley WH, Gething PW, Van Boeckel T, Kabaria CW, Harbach RE, Hay SI 2010. The dominant Anopheles vectors of human malaria in the Americas: occurrence data, distribution maps and bionomic precis. Parasit Vectors 3: 72.

SIVIGILA - Sistema Nacional de Vigilancia en Salud Pública 2013. Vigilancia rutinaria. Available from: ins.gov.co/lineas-de-accion/ Subdireccion-Vigilancia/sivigila/Paginas/vigilancia-rutinaria.aspx.

WHO - World Health Organization 2012. Global Malaria program 2012. World Malaria Report 2012. Available from: who.int/malaria/publications/world_malaria_report_2012/wmr2012_full_report.pdf.

Zimmerman RH 1992. Ecology of malaria vectors in the Americas and future direction. Mem Inst Oswaldo Cruz 87 (Suppl. III): 371-383. 